\title{
Grid Computing Research from India: A Bibliometric Assessment of Publications during 2008-2017
}

\section{B.M. Gupta*, Faizul Nisha**, Rajpal Walke*** and Ashok Kumar****}

To Cite: Gupta, B.M., Nisha, F., Walke, R. \& Kumar, A. (2018). Grid computing research from India: A bibliometric assessment of publications during 2008-2017. International Journal of Information Dissemination and Technology, 8(4), 190-195.

*Formerly with

CSIR-NISTADS

New Delhi-Bharat

**Defence Scientific

Information \& Documentation

Centre, Delhi-Bharat

${ }^{* * *}$ CSIR-NPL Library

New Delhi-Bharat

${ }^{* * * *}$ Chief Librarian

Maharishi Markandeshwar

(Deemed to be University)

Central Library

Mullana, Ambala-Bharat

Corresponding Author

Ashok Kumar

gargasok@gmail.com

\begin{abstract}
The paper examines quality and quantity of scientific research in India as reflected in publications output on grid computing on a series of bibliometric indicators. Data were extracted from Scopus database consisting of 1340 publications in grid computing research from India in 10 years during 2008-17 citation impact of 4.33 citations per paper and international collaborative publication share of $12.16 \%$. The paper profiles global publication output and share of 10 most productive countries in grid computing research, 15 most productive Indian organizations and 15 most productive authors on a series of indicators including publications output, number of citations, the relative citation index, citations per paper, h-index and share of international collaborative papers during 2008-17. Computer science, among top 3 subjects, accounted for the largest publication share $(90.15 \%)$, followed by engineering (26.79\%) and mathematics (13.66\%). The 15 most leading organizations and authors together contributed $31.57 \%$ and $14.25 \%$ as their share of Indian publication output and $44.93 \%$ and $16.17 \%$ as their share of Indian citation output respectively during 2008-17. The most productive Indian organizations were Anna University, Chennai (74 papers) and Thapar University, Patiala (48 papers) The most productive authors were I. Chana of Thapar University, Patiala (21 papers) and N. Mukherjee of Jadavpur University, Kolkata (18 papers). The 15 most productive journals contributed $43.92 \%$ share to the Indian journal publication output during 2008-17. The most productive journals were Applied Engineering Research (16 publications), Journal of Grid Computing (14 publications) and Future Generation Computer Systems (13 publications),
\end{abstract}

KeyTerms: Grid Computing, Indian Publications, Scientometrics, Bibliometrics

\section{TIME LAG}

$\begin{array}{ll}\text { Received on } & : 17.10 .18 \\ \text { Revised on } & : 19.12 .18 \\ \text { Accepted on } & : 25.12 .18\end{array}$

\begin{tabular}{|c|}
\hline Online Access \\
\hline www.ijidt.com \\
\hline DOI \\
$10.5958 / 2249-5576.2018 .00041 .9$ \\
\hline
\end{tabular}

QR Barcode



\section{INTRODUCTION}

After conceiving the idea of grid computing, lan Foster and his group in late' 90 s started a project called Globus as a cooperative effort of several interested organizations (mainly universities and national laboratories in the USA) to implement the idea. The Globus project (www.globus.org) defined grid computing as: "An infrastructure that enables the integrated, collaborative use of high-end computers, networks, databases, and scientific instruments owned and managed by multiple organizations". It was later refined to include the fact that there was no centralized control. The addition to the definition stated: "A system that coordinates resources that is not subject to centralized control using standards, open general purpose protocols, and interfaces to deliver the non-trivial quality of service." Another definition which emphasizes aggregation of distributed highperformance computers to obtain extremely high computing capacity to solve a single problem is given below: "Grid computing provides the ability using a set of open standards and protocols to gain access to applications and data, processing power, storage capacity and a vast array of computing resources over the Internet. It is a type of parallel and distributed system that enables the sharing, selection, and aggregation of resources distributed across multiple administrative domains based on their availability, capacity, performance, cost, and users' quality of service requirements"'.

The major Indian National Grid Computing initiative was GARUDA. C-DAC launched the Indian National Grid Computing Initiative-GARUDA with the support of 
Government of India. GARUDA is a collaboration of science researchers and experimenters, on a nationwide grid of computational nodes, mass storage and scientific instruments. GARUDA aims to provide the technological development required to enable data and compute intensive, collaborative applications for the 21 st century. In the PoC Phase of this project, a nation-wide grid test bed was enabled to its partners. In GARUDA Foundation Phase, an open standards based production grid, i.e. both a service grid as-well-as interoperable grid is built and enabled. Partners are grid enabling applications of societal and national importance.

Among other major grid computing initiative in education in India include: (i) BIOGRID-It is a high speed and high bandwidth virtual public network (VPN) established by The Department of Biotechnology, Govt of India. It is envisioned that the BIOGRID will span all the 60+ Bioinformatics centers of the Department of Biotechnology with Gbps bandwidth and 10+ Teraflops of computational power; (ii) C. Kerala Education Grid-The Kerala Education Grid provides webbased course content as well as various collaboration tools such as message board, discussion boards, shared web space, Chats, asynchronous interaction between students or between students and teachers. The digital content includes streaming videos, technical and scientific journals and publications etc.; (iii a) Sun Microsystems Inc has named Indian Institute of Information Technology and Management-Kerala (IIITMK) as a Sun Regional Center of Excellence (COE) for E-Learning. The first regional $\mathrm{COE}$ selected in India, IIITM K becomes one of the four universities in the world to be recognized by Sun and the academic community as leading-edge researchers in e-learning technologies; (v) b) IIT Kanpur is deploying Grid Computing hardware and software from Sun India, for its computer centre. The installation will make it the largest AMD Opteron HPTC (High-Performance Technical Computing) cluster in the education segment in India. These companies used Grid Computing effectively to achieve considerable cost and productivity advantages and (vi) c) The efforts of Anna University's, Madras Institute of Technologies (MIT), who partnered with C-DAC in developing Grid technologies and applications are worth mentioning as they are also making Grids interfaces available in Indian languages. One of their efforts was the development of Tamil (a language spoken in the south Indian state of Tamil Nadu) interface for their Grid Market Directory (GMD) user-interface. They also developed a Linux shell UI in Tamil. This is probably the world's first Grid technology with non-English language interface ${ }^{2-3 .}$ Several Indian IT companies too are investing a lot in the research and development of grid computing technology. Though grid computing is presently at a fairly nascent stage, it is seen as a cutting-edge technology.

\section{LITERATURE REVIEW}

Only one scientometric study has been undertaken on this theme. Santha Kumar analyzed 8950 global publications on grid computing during 2006-15 with a focus on annual growth rate, relative growth rate and doubling time of publications, identification of most prolific authors, highly productive countries, highly productive institutes, most preferred source titles for publication, language-wise distribution of publications and high productive subject areas. Similar other bibliometric studies have been undertaken on the other areas of computer science, such as overall computer science $^{4-7}$, cloud computing ${ }^{8-9}$, pervasive and ubiquitous computing ${ }^{10}$, quantum computing", supercomputing ${ }^{12}$, mobile cloud computing ${ }^{13}$, mobile computing ${ }^{14}$.

\section{OBJECTIVES}

- The growth and distribution of world and top 10 countries output and Indian literature on grid computing .

- International collaboration and identification of major collaborators with India

- The distribution of India's publication output by broad subject areas

- The scientometric profile of 10 most productive countries, 15 most productive Indian organizations and 15 most productive Indian authors

- The leading medium of communication in India

\section{Methodology}

The global publications of top 10 countries in grid computing were sourced from Scopus international database using a keyword "grid computing" for the years 2008 to 2017. The "Article title" or "Keyword" (as shown in the search string below) tags were searched for the keyword restricting the hit to the period 2008-17 in "date range tag". This statement became the main search string. The main search string was further restricted to 10 countries one by one in "country tag" for obtaining publication information of these countries (as shown below for India). On further restricting India's main search string (as provided in analytical functions of Scopus database) by "subject area tag", "country tag", "source title tag", "journal title name" and "affiliation tag", statistics on distribution of publications by subject, collaborating countries, author-wise, organization-wise and journal-wise were obtained. Separate search strategies were also developed to get information on different type of anemia research (as shown below). Citations data was obtained from the date of publication till 20 August 2018.

(KEY ("grid computing") OR TITLE ("grid computing") OR SRCTITLE ("grid computing")) AND PUBYEAR > 2007 AND PUBYEAR $<2018$

(KEY ("grid computing") OR TITLE ("grid computing") OR SRCTITLE ("grid computing")) AND PUBYEAR > 2007 AND PUBYEAR < 2018 AND ( LIMIT-TO ( AFFILCOUNTRY,"India") )

\section{DATA ANALYSIS}

\section{O Annual Publications Output}

The global and Indian research on grid computing consisting of 11023 and 1340 publications were derived from Scopus database. The annual and cumulative publication of world decreased from 1939 to 492 from the year 2008 to the year 2017. The world cumulative output (computed in 5 years) in grid computing research decreased from 7901 to 3122 and India's output also decreased from 694 to 646 from 2008- 12 to 2013-17 registering $-60.49 \%$ and $-7.49 \%$. India's global share in grid computing research averaged to $12.16 \%$ during $2008-17$, which increased from $8.78 \%$ during $2008-12$ to $20.68 \%$ during 2013-17. On measuring the impact of publications in terms of citations per paper, it was observed Indian publications on grid computing research averaged to 4.33 citations per publication. Which decreased from 5.90 CPP during 2008-12 to 2.56 CPP during 2013-17 (table 1). Of the total Indian publications output, $77.69 \%$ (1041) was published as 
conference papers, $21.27 \%$ (285) as articles, and others as reviews (7), book chapters (5) and articles in press (2).

Table 1: Annual Publications Output by India and World on Grid Computing Research

\begin{tabular}{|l|c|c|c|c|c|c|c|c|c|}
\hline \multirow{2}{*}{ Period } & \multicolumn{5}{|c|}{ World } & \multicolumn{6}{c|}{ India } \\
\cline { 2 - 10 } & TP & TC & CPP & TP & TC & CPP & \%TP & ICP & $\%$ ICP \\
\hline 2008 & 1939 & 19159 & 9.88 & 50 & 338 & 6.76 & 2.58 & 8 & 16 \\
\hline 2009 & 1896 & 14612 & 7.71 & 71 & 313 & 4.41 & 3.74 & 9 & 12.68 \\
\hline 2010 & 1748 & 22114 & 12.65 & 151 & 798 & 5.28 & 8.64 & 9 & 5.96 \\
\hline 2011 & 1141 & 9774 & 8.57 & 190 & 1856 & 9.77 & 16.65 & 9 & 4.74 \\
\hline 2012 & 1177 & 9232 & 7.84 & 232 & 844 & 3.64 & 19.71 & 9 & 3.88 \\
\hline 2013 & 617 & 4797 & 7.77 & 78 & 426 & 5.46 & 12.64 & 3 & 3.85 \\
\hline 2014 & 627 & 3235 & 5.16 & 114 & 390 & 3.42 & 18.18 & 9 & 7.89 \\
\hline 2015 & 695 & 2640 & 3.80 & 164 & 433 & 2.64 & 23.60 & 8 & 4.88 \\
\hline 2016 & 691 & 1517 & 2.20 & 232 & 212 & 0.91 & 33.57 & 9 & 3.88 \\
\hline 2017 & 492 & 548 & 1.11 & 58 & 192 & 3.31 & 11.79 & 6 & 10.34 \\
\hline $2008-12$ & 7901 & 74891 & 9.48 & 694 & 4149 & 5.90 & 8.78 & 47 & 6.77 \\
\hline $2013-17$ & 3122 & 12737 & 4.08 & 646 & 1653 & 2.56 & 20.68 & 35 & 5.42 \\
\hline $2008-17$ & 11023 & 87628 & 7.95 & 1340 & 5802 & 4.33 & 12.16 & 82 & 6.12 \\
\hline TP=Total Papers; TC=Total Citations; CPP=Citations Per Paper; \\
\hline
\end{tabular}

\section{O International Collaboration}

$12.16 \%$ of the total research output by India in grid computing research was published as international collaborative papers. India's collaborative output increased from $8.78 \%$ during $2008-12$ to $20.69 \%$ during $2013-17$. The leading foreign countries that collaborated with India in grid computing research were: USA (36.59\% publication share), followed by Australia (9.56\%), U.K. (8.54\%), Italy, Canada, Malaysia and South Korea (6.1\% each), Switzerland and U.A.E (3.66\% each) and Brazil (2.44\%) during 2008-17.

\section{O Most Productive Countries Contribution in Grid Computing Research}

The global grid computing research witnessed the participation of 118 countries during 2008-17, of which 50
10.5958/2249-5576.2018.00041.9 Table 2: Publication Share of Leading Foreign Countries in India's Collaborative Papers (ICP) Output in Grid Computing Researchc

\begin{tabular}{|c|c|c|c|c|c|c|c|}
\hline \multirow[t]{2}{*}{ S. No } & \multirow{2}{*}{$\begin{array}{l}\text { Collaborative } \\
\text { Country }\end{array}$} & \multicolumn{3}{|c|}{ ICP } & \multicolumn{3}{|c|}{ Share of ICP } \\
\hline & & $\begin{array}{c}2008- \\
12\end{array}$ & $\begin{array}{c}2013- \\
17\end{array}$ & $\begin{array}{c}2008- \\
17\end{array}$ & $\begin{array}{c}2008- \\
12\end{array}$ & $\begin{array}{l}2013- \\
17\end{array}$ & 2008-17 \\
\hline 1 & USA & 18 & 12 & 30 & 38.30 & 34.29 & 36.59 \\
\hline 2 & Australia & 3 & 5 & 8 & 6.38 & 14.29 & 9.56 \\
\hline 3 & U.K & 7 & 0 & 7 & 14.89 & 0 & 8.54 \\
\hline 4 & Italy & 3 & 2 & 5 & 6.38 & 5.71 & 6.1 \\
\hline 5 & Canada & 3 & 2 & 5 & 6.38 & 5.71 & 6.1 \\
\hline 6 & Malaysia & 0 & 5 & 5 & 0 & 14.29 & 6.1 \\
\hline 7 & South Korea & 2 & 3 & 5 & 4.26 & 8.57 & 6.1 \\
\hline 8 & Switzerland & 3 & 0 & 3 & 6.38 & 0 & 3.66 \\
\hline 9 & U.A.E & 0 & 3 & 3 & 0 & 8.57 & 3.66 \\
\hline \multirow[t]{2}{*}{10} & Brazil & 0 & 2 & 2 & 0 & 5.71 & 2.44 \\
\hline & Indian Total & 47 & 35 & 82 & -- & -- & -- \\
\hline \multicolumn{8}{|c|}{ ICP $=$ International Collaborative Papers } \\
\hline
\end{tabular}

countries contributed 1-10 papers each, 32 countries 11-50 papers each, 12 countries 51-100 papers each, 14 countries 101-500 papers each, 5 countries 501-1000 papers each, 2 countries 1001-2000 papers each and 1 country 2254 papers during 2008-17.

However, the top 10 countries together alone accounted for $81.27 \%$ global publication share and $85.67 \%$ global citation share. The cumulative publication share of top 10 countries showed a decrease from $81.60 \%$ during $2008-12$ to $80.43 \%$ during 2013-17. Individually, the top 10 countries publications ranged from 328 to 2254 and accounted for $2.98 \%$ to $20.45 \%$ of global publication share. China, among 10 top countries, accounted for the largest publication share $(20.45 \%)$, followed by USA (15.96), India (12.16\%) and other seven counties (from $2.98 \%$ to $6.17 \%$ ). Five countries which showed increase in their global publication share in five years namely India, USA, Spain and France (from $0.08 \%$ to $11.91 \%$ ), as against decrease in their global publication in China, Germany, UK, Japan, Italy and South Korea (from $0.11 \%$ to 9.27\%) from 2008-12 to 2013-17. Five countries registered relative citation index above their average of 1.05: USA (1.88) Germany (1.35), France (1.31), UK (1.28) and Italy (1.07) (table 3).

Table 3: Publication Output and Global Publication Share (\%age) of Top 10 Most Productive Countries in Grid Computing

\begin{tabular}{|c|c|c|c|c|c|c|c|c|c|c|c|c|}
\hline \multirow[t]{2}{*}{ S.No } & \multirow[t]{2}{*}{ Country } & \multicolumn{3}{|c|}{ Papers } & \multicolumn{3}{|c|}{ Share of Papers } & \multirow[t]{2}{*}{$\mathrm{TC}$} & \multirow[t]{2}{*}{ CPP } & \multirow[t]{2}{*}{ ICP } & \multirow[t]{2}{*}{ \%ICP } & \multirow[t]{2}{*}{$\mathrm{RCl}$} \\
\hline & & $\begin{array}{c}2008- \\
12\end{array}$ & $\begin{array}{c}2013- \\
17\end{array}$ & 2008-17 & $\begin{array}{c}2008- \\
12\end{array}$ & $\begin{array}{c}2013- \\
17\end{array}$ & $\begin{array}{c}2008- \\
17\end{array}$ & & & & & \\
\hline 1 & China & 1823 & 431 & 2254 & 23.07 & 13.81 & 20.45 & 11573 & 5.13 & 351 & 15.57 & 0.65 \\
\hline 2 & USA & 1225 & 534 & 1759 & 15.50 & 17.10 & 15.96 & 26324 & 14.97 & 598 & 34 & 1.88 \\
\hline 3 & India & 694 & 646 & 1340 & 8.78 & 20.69 & 12.16 & 5802 & 4.33 & 79 & 5.90 & 0.54 \\
\hline 4 & UK & 536 & 144 & 680 & 6.78 & 4.61 & 6.17 & 6929 & 10.19 & 357 & 52.50 & 1.28 \\
\hline 5 & Germany & 503 & 134 & 637 & 6.37 & 4.29 & 5.78 & 6853 & 10.76 & 262 & 41.13 & 1.35 \\
\hline 6 & Italy & 423 & 149 & 572 & 5.35 & 4.77 & 5.19 & 4884 & 8.54 & 198 & 34.62 & 1.07 \\
\hline 7 & France & 381 & 153 & 534 & 4.82 & 4.90 & 4.84 & 5554 & 10.40 & 292 & 54.68 & 1.31 \\
\hline 8 & Spain & 347 & 156 & 503 & 4.39 & 5 & 4.56 & 3612 & 7.18 & 231 & 45.92 & 0.90 \\
\hline 9 & South Korea & 254 & 97 & 351 & 3.21 & 3.11 & 3.18 & 1626 & 4.63 & 71 & 20.23 & 0.58 \\
\hline 10 & Japan & 261 & 67 & 328 & 3.30 & 2.15 & 2.98 & 1917 & 5.84 & 94 & 28.66 & 0.74 \\
\hline & Total & 6447 & 2511 & 8958 & 81.60 & 80.43 & 81.27 & 75074 & 8.38 & 2533 & 28.28 & 1.05 \\
\hline & World Total & 7901 & 3122 & 11023 & -- & -- & -- & 87628 & 7.95 & -- & -- & -- \\
\hline & $\begin{array}{l}\text { The share of } 10 \\
\text { Countries in World } \\
\text { Total }\end{array}$ & 81.60 & 80.43 & 81.27 & -- & -- & -- & 85.67 & -- & -- & -- & -- \\
\hline
\end{tabular}

\section{Subject-Wise Distribution of Indian Research Papers}

Grid computing research output from India was classified under three broad subjects (as defined by the Scopus database). Computer science accounted for the largest publication share $(90.15 \%)$, followed by engineering $(26.79 \%)$ and mathematics (13.66\%). The activity index showed an increase in publication activity in engineering (from $44.67 \%$ to $159.47 \%$ ), as against 
decrease in computer science (from 103.10 to 96.67) and mathematics (from 120.28 to 78.21 ) from 2008-12 to 2013-17. The average value of the activity index is 100. Mathematics registered the highest citation of 5.46 per paper, followed by computer science (4.12) and engineering (2.76) during 200817 (Table 4).

\begin{tabular}{|c|c|c|c|c|c|c|c|c|c|}
\hline \multirow{2}{*}{\begin{tabular}{|l} 
S. \\
No.
\end{tabular}} & \multirow[t]{2}{*}{ Subject* } & \multicolumn{3}{|c|}{ Papers (TP) } & \multicolumn{2}{|c|}{ Activity Index } & \multirow{2}{*}{\begin{tabular}{|c|} 
TC \\
$2008-$ \\
17
\end{tabular}} & \multirow{2}{*}{\begin{tabular}{|c|} 
CPP \\
$2008-$ \\
17
\end{tabular}} & \multirow{2}{*}{$\begin{array}{c}\% \text { TP } \\
2008 \\
17\end{array}$} \\
\hline & & $\begin{array}{l}2008- \\
12\end{array}$ & \begin{tabular}{|c|}
$2013-$ \\
17
\end{tabular} & $\begin{array}{l}2008- \\
12\end{array}$ & $\begin{array}{c}2008- \\
12\end{array}$ & $\begin{array}{c}2013- \\
17\end{array}$ & & & \\
\hline 1 & $\begin{array}{l}\text { Computer } \\
\text { Science }\end{array}$ & 645 & 563 & 1208 & \begin{tabular}{|l|}
103.10 \\
\end{tabular} & 96.67 & \begin{tabular}{|l|}
4980 \\
\end{tabular} & 4.12 & 90.15 \\
\hline 2 & Engineering & 83 & 276 & 359 & $\begin{array}{l}44.67 \\
\end{array}$ & 159.47 & 990 & 2.76 & 26.79 \\
\hline 3 & Mathematics & 114 & 69 & 183 & 120.28 & 78.21 & 999 & 5.46 & 13.66 \\
\hline & Total & 694 & 646 & 1340 & -- & -- & -- & -- & -- \\
\hline
\end{tabular}

Top 15 Most Productive Indian Organizations Contribution and Impact

228 organizations participated in India's grid computing research, of which 206 organizations contributed 1-5 papers each, 50 organizations 6-10 papers each, 23 organizations 11-20 papers each, 8 organizations 21-50 papers each and 1 organization 74 papers during 2008-17.

The 15 most productive organizations together contributed 423 publications (31.57\% share) and 2607 citations $(44.93 \%$ share) in India's output during 2008-17. Individually the top 15 organizations contribution varied from 17 to 74 in 10 years (Table 5).

Only six organizations registered productivity rate above the group average of 28.2 per organization: Anna University, Chennai (74 papers) and Thapar University, Patiala (48 papers), Jawaharlal Nehru University, New Delhi, Jadavpur

\begin{tabular}{|c|c|c|c|c|c|c|c|c|}
\hline S. & Organization & TP & TC & CPP & $\mathrm{HI}$ & ICP & \%ICP & $\mathrm{RCl}$ \\
\hline 1 & Anna University, Chennai & 74 & 1381 & 18.66 & 9 & 6 & 8.11 & 4.31 \\
\hline 2 & Thapar University, Patiala & 48 & 276 & 5.75 & 9 & 4 & 8.33 & 1.33 \\
\hline 3 & $\begin{array}{l}\text { Jawaharlal Nehru University, } \\
\text { New Delhi }\end{array}$ & 35 & 146 & 4.17 & 8 & 0 & 0 & 0.96 \\
\hline 4 & Jadavpur University, Kolkata & 32 & 108 & 3.38 & 6 & 2 & 6.25 & 0.78 \\
\hline 5 & $\begin{array}{l}\text { Jaypee Universityof } \\
\text { Information Technology, } \\
\text { Kandaghat, Himachal Pradesh }\end{array}$ & 30 & 84 & 2.80 & 6 & 0 & 0 & 0.65 \\
\hline 6 & $\begin{array}{l}\text { National Institute of } \\
\text { Technology, Kurukshetra }\end{array}$ & 29 & 87 & 3 & 6 & 0 & 0 & 0.69 \\
\hline 7 & C-DAC, India & 23 & 33 & 1.43 & 3 & 0 & 0 & 0.33 \\
\hline 8 & $\begin{array}{l}\text { Osmania University, } \\
\text { Hyderabad }\end{array}$ & 22 & 111 & 5.05 & 7 & 4 & 18.18 & 1.17 \\
\hline 9 & Vellore Institute of Technology & 21 & 19 & 0.90 & 3 & 4 & 19.05 & 0.21 \\
\hline 10 & $\begin{array}{l}\text { Indian Institute of Science, } \\
\text { Bangalore }\end{array}$ & 19 & 120 & 6.32 & 7 & 2 & 10.53 & 1.46 \\
\hline 11 & $\begin{array}{l}\text { J.N.Technological University, } \\
\text { Hyderabad }\end{array}$ & 19 & 65 & 3.42 & 5 & 0 & 0 & 0.79 \\
\hline 12 & $\begin{array}{l}\text { Karunya Institute of } \\
\text { Technology \& Science }\end{array}$ & 19 & 53 & 2.79 & 4 & 0 & 0 & 0.64 \\
\hline 13 & Madras Institute of Technology & 18 & 40 & 2.22 & 3 & 3 & 16.67 & 0.51 \\
\hline 14 & University of Hyderabad & 17 & 51 & 3 & 4 & 3 & 17.65 & 0.69 \\
\hline 15 & $\begin{array}{l}\text { Jaypee Institute of Information } \\
\text { Technology, Noida }\end{array}$ & 17 & 33 & 1.94 & 3 & 1 & 5.88 & 0.45 \\
\hline & Total of 15 organizations & 423 & 2607 & 6.16 & 5.53 & 29 & 6.86 & 1.42 \\
\hline & Total of India & 1340 & 5802 & 4.33 & -- & -- & -- & -- \\
\hline & $\begin{array}{l}\text { The share of top } 15 \\
\text { organizations in India total } \\
\text { output }\end{array}$ & 31.57 & 44.93 & -- & -- & -- & -- & -- \\
\hline \multicolumn{9}{|c|}{$\begin{array}{c}\text { TP=Total Papers; TC=Total Citations; CPP=Citations Per Paper; } \\
\mathrm{HI}=\mathrm{h} \text {-index; ICP=International Collaborative Papers; } \mathrm{RCl}=\text { Relative } \\
\text { Citation Index }\end{array}$} \\
\hline
\end{tabular}

University, Kolkata and Jaypee University of Information Technology, Kandaghat, Himachal Pradesh (30 papers) and National Institute of Technology, Kurukshetra. from 35 papers to 17 papers. Only two organizations registered citation impact and relative citation index above the group average of 6.16 citations per publication and 1.42: Anna University, Chennai (18.66 and 4.31) and Indian Institute of Science, Bangalore (6.32 and 1.46). Seven organizations registered international collaborative publications above the group average of $6.86 \%$ : Vellore Institute of Technology (19.05\%), Osmania University, Hyderabad (18.18\%), University of Hyderabad (17.65\%), Madras Institute of Technology (16.67\%), Indian Institute of Science, Bangalore (10.53\%), Thapar University, Patiala (8.33\%) and Anna University, Chennai (8.11\%) (table 5).

\section{Top 15 Most Productive Indian Authors Contribution and Impact}

547 authors participated in India's grid computing research, of which 505 authors contributed 1-5 papers each, 35 authors 6-10 papers each, 6 authors 11-20 papers each and 1 author 21 papers during 2008-17.

The top 15 most productive authors contributed 8 to 21 papers each, and together they contributed 191 papers (14.25\%) and received 938 citations (16.17\%) during 2008-17 (table 6).

Seven authors registered publication productivity above the group average of 14.25: I. Chana (21 papers), N. Mukherjee (18 papers), S. Ramachandran, Z. Raza and D.P. Vidyarthi(16 papers each), A. Aggarwal and T.S. Somasundaran (15 papers each), Four authors registered impact and relative citation index above the group average of 4.91 citations per publication and 1.13: I. Chana (9.86 and 2.28), W. Abdulal (8.38 and 1.93), R. Sharma (6.0 and 1.39), V.K. Soni (6 and 1.39), M.K. Mishra (5.9 and 1.36), S. Roy(5.11 and 1.18) and D.P. Vidyarthi (5.06 and 1.17); and Four authors registered international collaborative publications (ICP) share more than the average ICP share (6.81\%): W. Abdulal (37.5\%), T.S.Somasundaran (33.33\%), S. Ramachandran (12.5\%) and I. Chana (9.52\%).

\section{Distribution of Publications by Source and Channel of Communication}

Of the 1340 publications by India in grid computing research, $64.18 \%$ (860) appeared in conferences, $11.09 \%$ (296) in journals, $13.43 \%$ (180) in book series and $0.30 \%$ (4) as books during 2008-17. The top 15 most productive journals (with contributions from 4 to 16 papers) together contributed 130 publications (43.92\% share of total journal output) during 2008-17. The cumulative five-year journal publication output reported in 15 journals decreased from $49.57 \%$ during 2008-12 to $40.33 \%$ during $2013-17$. The leading journals contributing to Indian research in grid computing research are listed in table 6: International Journal of Applied Engineering Research (16 publications), followed by Journal of Grid Computing (14 publications), Future Generation Computer Systems (13 publications), Journal of Computer Science (11 publications), etc. 
Table 6: Scientometric Profile of Top 15 Most Productive Indian Authors in Anemia Research

\begin{tabular}{|c|c|c|c|c|c|c|c|c|c|}
\hline S.No & Author & Affiliation of the Author & TP & TC & CPP & HI & ICP & \%ICP & $\mathrm{RCl}$ \\
\hline 1 & I. Chana & Thapar University, Patiala & 21 & 207 & 9.86 & 7 & 2 & 9.52 & 2.28 \\
\hline 2 & N. Mukherjee & Jadavpur University, Kolkata & 18 & 68 & 3.78 & 5 & 0 & 0 & 0.87 \\
\hline 3 & S.Ramachandran & Osmania University, Hyderabad & 16 & 70 & 4.38 & 5 & 2 & 12.50 & 1.01 \\
\hline 4 & Z.Raza & Jawaharlal Nehru University, New Delhi & 16 & 54 & 3.38 & 5 & 0 & 0 & 0.78 \\
\hline 5 & D.P. Vidyarthi & Jawaharlal Nehru University, New Delhi & 16 & 81 & 5.06 & 5 & 0 & 0 & 1.17 \\
\hline 6 & A.Aggarwal & $\begin{array}{l}\text { JP Institute of Engineering \& Technology, } \\
\text { Meerut }\end{array}$ & 15 & 22 & 1.47 & 2 & 1 & 6.67 & 0.34 \\
\hline 7 & T.S. Somasundaran & Madras Institute of Technology & 15 & 63 & 4.20 & 5 & 5 & 33.33 & 0.97 \\
\hline 8 & P.M.Khilar & National Institute of Technology, Rourkela & 10 & 29 & 2.90 & 3 & 0 & 0 & 0.67 \\
\hline 9 & M.K.Mishra & $\begin{array}{l}\text { Kalinga Institute of Technology, } \\
\text { Bhubaneshwar }\end{array}$ & 10 & 59 & 5.90 & 5 & 0 & 0 & 1.36 \\
\hline 10 & A.K.Sin gh & National Institute of Technology, Kurukshetra & 10 & 42 & 4.20 & 4 & 0 & 0 & 0.97 \\
\hline 11 & S.K.Panda & Indian School of Mines, Dhanbad & 9 & 22 & 2.44 & 3 & 0 & 0 & 0.56 \\
\hline 12 & S.Roy & Jadavpur University, Kolkata & 9 & 46 & 5.11 & 5 & 0 & 0 & 1.18 \\
\hline 13 & R.Sharma & $\begin{array}{l}\text { Kalinga Institute of Technology, } \\
\text { Bhubaneshwar }\end{array}$ & 9 & 54 & 6 & 5 & 0 & 0 & 1.39 \\
\hline 14 & V.K.Soni & $\begin{array}{l}\text { Kalinga Institute of Technology, } \\
\text { Bhubaneshwar }\end{array}$ & 9 & 54 & 6 & 5 & 0 & 0 & 1.39 \\
\hline \multirow[t]{4}{*}{15} & W.Abdulal & Osmania University, Hyderabad & 8 & 67 & 8.38 & 6 & 3 & 37.5 & 1.93 \\
\hline & & Total of 15 authors & 191 & 938 & 4.91 & 6.47 & 13 & 6.81 & 1.13 \\
\hline & & Total of India & 1340 & 5802 & 4.33 & - & - & -- & -- \\
\hline & & Share of 15 authors in India's total & 14.25 & 16.17 & 1.13 & -- & -- & -- & -- \\
\hline \multicolumn{10}{|c|}{$\begin{aligned} \text { TP=Total Papers; } \mathrm{TC}=\text { Total Citations; } \mathrm{CPP}= & \text { Citations Per Paper; } \mathrm{HI}=\mathrm{h} \text {-index; } \mathrm{ICP}=\text { International Collaborative Papers; } \\
& \text { RCl=Relative Citation Index }\end{aligned}$} \\
\hline
\end{tabular}

Table 7: Top 15 Most Productive Journals Reporting Output from Indian Scholars

\begin{tabular}{|l|l|c|c|c|}
\hline \multirow{2}{*}{ S.No } & Journal & \multicolumn{3}{|c|}{ Papers } \\
\cline { 3 - 5 } & & $\begin{array}{c}2008- \\
12\end{array}$ & $\begin{array}{c}2013- \\
17\end{array}$ & $\begin{array}{c}\text { 2008- } \\
17\end{array}$ \\
\hline 1 & $\begin{array}{l}\text { International Journal of Applied Engineering } \\
\text { Research }\end{array}$ & 0 & 16 & 16 \\
\hline 2 & Journal of Grid Computing & 6 & 8 & 14 \\
\hline 3 & Future Generation Computer Systems & 9 & 4 & 13 \\
\hline 4 & Journal of Computer Science & 8 & 3 & 11 \\
\hline 5 & $\begin{array}{l}\text { International Journal of Grid \& High } \\
\text { Performance Computing }\end{array}$ & 5 & 5 & 10 \\
\hline 6 & $\begin{array}{l}\text { International Journal of Communication } \\
\text { Networks \& Distributed Systems }\end{array}$ & 6 & 3 & 9 \\
\hline 7 & European Journal of Scientific Research & 8 & 0 & 8 \\
\hline 8 & $\begin{array}{l}\text { International Journal of Grid \& Utility } \\
\text { Computing }\end{array}$ & 2 & 6 & 8 \\
\hline 9 & $\begin{array}{l}\text { World Academy of Science, Engineering \& } \\
\text { Technology }\end{array}$ & 8 & 0 & 8 \\
\hline 10 & $\begin{array}{l}\text { Journal of Theoretical \& Applied Information } \\
\text { Technology }\end{array}$ & 2 & 5 & 7 \\
\hline 11 & Asian Journal of Information Technology & 0 & 6 & 6 \\
\hline 12 & Journal of Supercomputing & 0 & 6 & 6 \\
\hline 13 & Multi -agents \& Grid Systems & 3 & 2 & 5 \\
\hline 14 & $\begin{array}{l}\text { Research Journal of Applied Sciences, } \\
\text { Engineering \& Technology }\end{array}$ & 0 & 5 & 5 \\
\hline 15 & Arabian Journal for Science \& Engineering & 0 & 4 & 4 \\
\hline \multirow{2}{*}{} & Total of 15 journals & 57 & 73 & 130 \\
\cline { 2 - 5 } & Total India journal output & 115 & 181 & 296 \\
\cline { 2 - 5 } & $\begin{array}{l}\text { The share of top 15durnals in Indian journal } \\
\text { output }\end{array}$ & 49.57 & 40.33 & 43.92 \\
\hline
\end{tabular}

\section{SUMMARY}

Grid computing research worldwide originated in 118 countries during 2008-17. 81.27\% of global cumulative publication share and $85.67 \%$ global cumulative citation share came from the top 10 most productive countries. However, the cumulative publication share of top 10 countries showed a decrease from $81.60 \%$ during 2008-12 to $80.43 \%$ during 2013-17. China, among top 10 countries, accounted for the highest publication share $(20.45 \%)$, followed by USA (15.96\%), India (12.16\%) and other seven counties (from 2.98\% to 6.17\%) during 2008-17.
India had published 1340 publications in grid computing research, which showed an increase from 50 in the year 2008 to 58 in the year 2017, averaging $21.41 \%$ annual growth rate. India's share in the global publication output in grid computing research was $12.69 \%$ during 2008-17, which showed an increase from $8.78 \%$ during $2008-12$ to $20.68 \%$ during 2013-17. India's citation impact in grid computing research averaged to 4.33 citations per publication during 2008-17, which dropped from 5.90 during 2008-12 to $2.56 \%$ during 2013-17. The share of India's international collaborative papers in national output was $12.16 \%$ during 2008-17, which showed an increase from $8.78 \%$ during $2008-$ 12 to $20.69 \%$ during 2013-17. The leading foreign countries collaborating with India were: USA $136.59 \%$ publication share), followed by Australia (9.56\%), U.K. (8.54\%), Italy, Canada, Malaysia and South Korea (6.1\% each), Switzerland and U.A.E (3.66\% each) and Brazil (2.44\%) during 2008-17.

The 15 most leading organizations and authors together contributed $31.57 \%$ and $14.25 \%$ as their share of Indian publication output and $44.93 \%$ and $16.17 \%$ as their share of Indian citation output respectively during 2008-17. Indian organizations, showing comparatively higher productivity in grid computing. Similarly, Indian organizations showing comparatively higher citation impact per paper and relative citation index were: Anna University, Chennai (18.66 and 4.31) and Indian Institute of Science, Bangalore (6.32 and 1.46).

Of the 1340 Indian publications on grid computing research, 296 papers appeared in journals. The 15 most productive journals contributed $43.92 \%$ share to the Indian journal publication output during 2008-17. The publication share in five years from top 15 journals decreased from $49.57 \%$ during 2008-12 to $40.33 \%$ during 2013-17.

\section{REFERENCES}

1. Rajaraman, V. (2016) Grid Computing. Resonance May, 401-4151.

2. Prahlada Rao, et al. (2009). E-Infrastructures in IT: A case study on Indian national grid computing initiativeGARUDA. Computer Science Research and Development, 23(3-4), 283-90. 
3. Sivagami, V.M. \& Muthuraj, R. (2003). Indian initiatives in grid computing with respect to education perspective. International Journal of Engineering Trends and Technology, 4(4), 636-42.

4. Gupta, B.M., Bala, A. \& Sharma, N. (2011). Ranking of Indian institutions contributing to computer science Research, 1999-2008. DESIDOC Journal of Library \& Information Technology, 31 (6), 460-68.

5. Gupta, B.M. \& Dhawan, S.M. (2017). Highly cited publications output by India in computer science 19962015: A scientometric assessment. Journal of Scientometric Research, 6(2), 74-85.

6. Gupta, B.M., Kshitij, A. \& Singh, Y. (2010). Indian computer science research output during 1999-2008: Qualitative analysis. DESIDOC Journal of Library and Information Technology, 30(6), 39-54.

7. Gupta, B.M.; Kshitiji, A. \& Verma, C. (2011). Mapping of Indian computer science research output, 1999-2008. Scientometrics, 86(2), 261-83.

8. Gupta, B.M., Singh, N. \& Gupta, R. (2015). Indian cloud computing research: A scientometric assessment of publications output during 2004-13. SRELS Journal of Information Management, 52(5), 315-326.
10.5958/2249-5576.2018.00041.9

9. Gupta, B.M., Singh, N. \& Gupta, R. (2015). International cloud computing literature: A scientometric analysis for 2004-13. Information Studies, 21 (2-3), 111 1-131.

10. Dhawan, S.M., Gupta, B.M. \& Gupta, R. (2016). Global pervasive and ubiquitous computing 2005-14. Annals of Library and Information Studies, 63(2), 117-25.

11. Dhawan, S.M., Gupta, B.M. \& Bhusan, S. (2018). Global publications output on quantum computing: A scientometric assessment during 2007-16. Emerging Science Journal, 2(4), 208-237.

12. Dhawan, S.M., Gupta, B.M. \& Gupta, R. (2018). Supercomputing: A scientometric assessment of global publications output during 2007-16. COLLNET Journal of Scientometrics \& Information Management, 12(2), 1-17.

13. Gupta, B.M., Dhawan, S.M. \& Gupta, R. (2017). Mobile cloud computing: A scientometric assessment of global publications output during 2007-16. Journal of Scientometric Research, 6(3), 186-194.

14. Dhawan, S.M., Gupta, B.M. \& Gupta, R. (2017). Mobile computing: A scientometric assessment of global publications output. Annals of Library \& Information Studies, 64(3), 172-180. 